\title{
High Voltage Vanadium-Metal Hydride Rechargeable Semi-Flow Battery
}

\author{
Guo-Ming Weng, Chi-Ying Vanessa Li*, and Kwong-Yu Chan* \\ Department of Chemistry, The University of Hong Kong, \\ Pokfulam Road, Hong Kong SAR, China
}

* Corresponding Authors

Tel: +(852) 2859 7917, Fax: +(852) 2857 1586, E-mail: hrsccky@hku.hk

\begin{abstract}
We report a vanadium-MH rechargeable semi-flow battery with an experimental OCV of $1.93 \mathrm{~V}$ and operating voltage of $1.70 \mathrm{~V}$, very high values among rechargeable flow batteries with aqueous electrolytes. This hybrid battery consists of a graphite felt positive electrode operating in a mixed solution of $0.128 \mathrm{~mol} \mathrm{dm}^{-3} \mathrm{VOSO}_{4}$ and $2 \mathrm{~mol} \mathrm{dm}^{-3} \mathrm{H}_{2} \mathrm{SO}_{4}$, and a metal hydride negative electrode in $2 \mathrm{~mol} \mathrm{dm}^{-3} \mathrm{KOH}$ aqueous solution. The two electrolytes of different $p H$ are separated by a bipolar membrane. The system demonstrated good reversibility and high efficiencies in coulomb (95\%), energy (83.7\%), and voltage (88.1\%).
\end{abstract}

Keywords: Acid alkaline hybrid rechargeable battery, Dual-electrolyte battery, Vanadium redox flow battery, Nickel metal hydride battery, Bipolar membrane. 


\section{Introduction}

Known since 1974, flow batteries ${ }^{1-9}$ are actively studied for storing electricity, intermittently generated from solar, wind, and other renewable sources ${ }^{10}$. During charging or discharging of a flow battery, reversible redox reactions occur in the electrolyte which can be stored in tanks external to the electrochemical cell. Hence energy capacity is proportional to the amount of the electrolyte and scaled independently from the cell, when proportional change in power is not required. The all-vanadium redox flow (VRF) battery ${ }^{11,12}$ is one of the most promising flow batteries, but still requires improvements and development ${ }^{13-16}$.

The theoretical specific energy of VRF battery is not high $\left(60.5 \mathrm{Wh} \mathrm{kg}^{-1}\right)$, and its cell voltage is inherently limited by the electrochemical window in aqueous electrolytes. Under standard conditions, the $1.23 \mathrm{~V}$ limit applies to acidic type cells such as hydrogenbromine ${ }^{17}$, Fe-Cr or Fe-Ti ${ }^{1-3}$ or alkaline type cells such as $\mathrm{Zn}$-air ${ }^{18}$, and Ni-hydrogen ${ }^{19}$, 20. The VRF battery is acidic and has a positive $\mathrm{V}^{4+} / \mathrm{V}^{5+}$ electrolyte at a standard potential of $1.0 \mathrm{~V}$ coupled with a negative electrolyte $\mathrm{V}^{2+} / \mathrm{V}^{3+}$ at $-0.26 \mathrm{~V}$, giving a theoretical cell voltage of $1.26 \mathrm{~V}$.

In addition to developing alternative stable electrolytes with a higher vanadium salt solubility ${ }^{11,12}$, serious attempts were made to improve vanadium flow battery technology by alternative pairing of negative and positive electrode/electrolyte reactions into a hybrid cell ${ }^{21-26}$. Skyllas-Kazacos et al. ${ }^{21}$ reported a hybrid Vanadium- $\mathrm{O}_{2}$ redox fuel cell, thus eliminating the mass of the positive side as oxygen can be freely stored in air. The reported specific energy is higher than $40 \mathrm{Wh} \mathrm{kg}^{-1}{ }^{21}$, about 1.6 times the practical specific energy of conventional VRF battery (25-35 $\left.\mathrm{Wh} \mathrm{kg}^{-1}\right)^{11,12}$, whereas the reported 
open circuit voltage (OCV) was kept in the range of 1.10 to $1.24 \mathrm{~V}$. The four electron oxygen reaction is known to be highly irreversible, thus the absence of a good bifunctional electrocatalyst leads to low voltage efficiency. Another combination was a vanadium chloride/polyhalide redox flow battery proposed by the same group ${ }^{26}$ to increase the specific energy, giving an experimental OCV of $1.3 \mathrm{~V}$. Crossover of ions through the membrane was reduced during operation. Both attempts give similar OCV to that of the conventional VRF battery, as shown in Table 1.

The soluble lead system ${ }^{27}$ is an attractive candidate with an alternative positive side at a higher potential. However, there are concerns of environmental impacts and stability of the lead compound. A rechargeable battery coupling $\mathrm{V}^{4+} / \mathrm{V}^{5+}$ with a different negative electrode/electrolyte, could be a better strategy than replacing the positive electrolyte in terms of higher cell voltage. Furthermore, the $\mathrm{V}^{2+} / \mathrm{V}^{3+}$ pair is found to be less stable in air (as $\mathrm{V}^{2+}$ ions is easily oxidized in air) ${ }^{11}$. If an alternative negative component from a matured electrochemical system has a potential lower than $-0.26 \mathrm{~V}$, a further gain in cell voltage and reduction in cost could be achieved.

Exploiting the $p H$ differential between an alkaline negative electrode and acidic positive electrode, a higher cell voltage has been demonstrated for $\mathrm{H}_{2}-\mathrm{O}_{2}$ fuel cells ${ }^{28-30}$ and $\mathrm{PbO}_{2} / \mathrm{PbSO}_{4}-\mathrm{MH}_{\mathrm{X}} / \mathrm{MH}_{\mathrm{x}-1}$ rechargeable batteries ${ }^{30-33}$. The latter system reported a stable operating voltage with repeated charge/discharge cycles at 2.6 V (corresponding to $30 \%$ and $86 \%$ increase in voltage from individual lead-acid and $\mathrm{NiMH}_{\mathrm{x}}$ batteries, respectively). The higher voltage and higher capacity achieved is a result of the extra energy store/released in acid-alkaline neutralization ${ }^{30,31,34}$ corresponding to $\Delta G^{\circ}=-79.85$ $\mathrm{kJ} \mathrm{mol}^{-1}$. 
A bipolar membrane, synthesized by laminating a cation membrane and an anion membrane together, has been applied to the separation of acids and bases. ${ }^{35,}{ }^{36}$ It was used here to provide the ionic contact as well as a barrier for proton and hydroxide ions transport in the $p H$ differential cells. ${ }^{29,} 30,32-34$ In principle, only uncharged species can penetrate both membranes and water enters and splits to $\mathrm{H}^{+}$and $\mathrm{OH}^{-}$to provide the ionic transport. However, at very low current, due to imperfect exclusion of co-ions, leakage current occurs. ${ }^{36}$ Therefore, $\mathrm{K}^{+}$and $\mathrm{HSO}_{4}{ }^{-}$can serve as charge carriers when a bipolar membrane separates $\mathrm{KOH}$ and $\mathrm{H}_{2} \mathrm{SO}_{4}$ solutions and operates at low current density. Membrane-less systems ${ }^{28,37}$ with flowing electrolytes have been reported to function by maintaining laminar flows in parallel without convective mixing and to prevent ionic conduction across the interface. The maximum reported operating voltage of a membrane-less all-vanadium redox flow battery is about $1.5 \mathrm{~V}^{37}$, and varies accordingly with state of charge, cell design and flow rate. Practical application of these membraneless systems is still limited by the poor utilization of fuel, limitation of mass transport, and the need of microfluidic flows ${ }^{38}$.

It is conceptually attractive to increase the voltage of vanadium flow battery by introducing a $p H$ differential through coupling the positive $\mathrm{V}^{4+} / \mathrm{V}^{5+}$ acidic compartment with a negative alkaline electrode/electrolyte. Additional neutralization energy can be stored in the electrolyte while liquid flow minimizes fouling and enhances the function of the ionic interfaces. In this paper, we apply the high voltage advantage of the acid/alkaline dual electrolyte concept to a flow battery system. Here, we investigate the feasibility of hybridizing an alkaline hydrogen cell with an acidic vanadium $\mathrm{V}^{4+} / \mathrm{V}^{5+}$ redox couple. Though not a full flow system, the alkaline metal hydride electrode has 
almost the same potential as alkaline hydrogen electrode and can be used here to demonstrate the technological principle. We report this high voltage semi-flow vanadium-metal hydride (V-MH) hybrid rechargeable battery with a setup as shown in Fig. 1. The electrochemical reactions of this V-MH semi-flow battery are illustrated in $2^{\text {nd }}$ last row of Table 1.

\section{Experimental}

Vanadium-MH semi-flow battery (V-MH) design.-The hybrid battery had two compartments as shown in Fig. 1. The acid chamber had a graphite-felt positive electrode immersed in a $20 \mathrm{~cm}^{3}$ solution containing $0.128 \mathrm{~mol} \mathrm{dm}^{-3} \mathrm{VOSO}_{4}$ and $2 \mathrm{~mol} \mathrm{dm}^{-3} \mathrm{H}_{2} \mathrm{SO}_{4}$. The alkaline chamber had a $\mathrm{MH}_{\mathrm{x}}$ negative plate immersed in a $20 \mathrm{~cm}^{3} 2 \mathrm{~mol} \mathrm{dm}^{-3} \mathrm{KOH}$ aqueous solution. The two chambers were separated by a $0.1 \mathrm{~cm}$ thick bipolar membrane CMI7000/AMI7001 from Membrane International Inc., USA. The active area of the bipolar membrane is $20 \mathrm{~cm}^{2}$ and the predicted electrical resistance is around $70 \mathrm{ohm} \mathrm{cm}$ in $0.5 \mathrm{~mol} \mathrm{dm}^{-3} \mathrm{NaCl}$ solution. The bipolar membrane was immersed in $5 \% \mathrm{NaCl}$ aqueous solution overnight before use. The dimension of each acid and alkaline electrolyte chamber was about $46 \mathrm{~mm}(\mathrm{~L}) \times 68 \mathrm{~mm}(\mathrm{H}) \times 10 \mathrm{~mm}(\mathrm{~W})$. The inter-electrode gap is $2 \mathrm{~cm}$ and there is no flow distributor to control the flow pattern. The volumetric flow rate was fixed at $10 \mathrm{~cm}^{3} \mathrm{~min}^{-1}$ corresponding to a linear flow rate of $79.6 \mathrm{~cm} \mathrm{~min}-1$ for the $\mathrm{VOSO}_{4} / \mathrm{H}_{2} \mathrm{SO}_{4}$ electrolyte in the positive chamber of Vanadium-MH system. Individual VRF and $\mathrm{NiMH}_{\mathrm{x}}$ batteries were assembled with same electrolyte concentration and operated at the same condition for comparison. Here, $\mathrm{M}$ represents a mischmetal (an 
alloy of rare eartg elements) that reversibly adsorbs hydrogen in the electrochemical reaction. Details of the metal are described below.

\section{Electrodes and electrolytes preparation.}

Commercial graphite felt from Shenhe Carbon Fiber Materials Co. Ltd., Liaoning, China, was used as positive electrode, with an active geometric area of around $9 \mathrm{~cm}^{2}$ and a thickness of $5 \mathrm{~mm}$. This graphite felt was pre-treated before use with the following steps. 1) Acid Pretreatment: The graphite felt (GF) was soaked in $95 \%$ (wt\%) $\mathrm{H}_{2} \mathrm{SO}_{4}$ at $50{ }^{\circ} \mathrm{C}$ for 4 hours. It was rinsed with DI water until the effluent $p H$ is near 7 and then heat treated at $60{ }^{\circ} \mathrm{C}$ for 2 hours to improve its electrochemical activity and hydrophilicity. 2) Electrochemical Pretreatment: The GF was electrochemically oxidized in $1 \mathrm{~mol} \mathrm{dm}^{-3}$ $\mathrm{H}_{2} \mathrm{SO}_{4}$ aqueous solution at $30 \mathrm{~mA} \mathrm{~cm}{ }^{-2}$ for 4 minutes. The counter electrode was a graphite plate and the reference electrode was a $\mathrm{Ag} / \mathrm{AgCl}$ electrode with $3 \mathrm{~mol} \mathrm{dm}^{-3} \mathrm{NaCl}$ filling solution. This step improved the reversibility of redox reaction in the positive chamber. The use of a $\mathrm{Hg} / \mathrm{HgSO}_{4}$ reference electrode is preferred and was tested later to give the same results of pretreatment. 3) After anodic polarization in step 2, the GF electrode was again rinsed with DI water until the effluent $p H$ was near 7. It was then dried at $60{ }^{\circ} \mathrm{C}$ for 2 hours and stored for later use. This pretreatment process can reduce activation polarization and improve reversibility as evident from the cyclic voltammograms in Fig. 2. The voltammogram for the pretreated GF electrode was for the $3^{\text {rd }}$ cycle, after which there was no further improvement in the overpotential.

The negative metal hydride $\left(\mathrm{MH}_{\mathrm{x}}\right)$ electrode was prepared by $1 \mathrm{~g}$ of $\mathrm{LaNi}_{5}$ based metal-hydride alloy powder extracted from a commercial GP-2700 AA battery. The 
$\mathrm{LaNi}_{5}$ based powder was mixed with $50 \mathrm{mg}$ XC-72 vulcan carbon (4.5 wt\%), pasted and pressed onto a piece of nickel foam. The active area of $\mathrm{MH}_{\mathrm{x}}$ electrode was around $9 \mathrm{~cm}^{2}$.

The initial $0.128 \mathrm{~mol} \mathrm{dm}^{-3}$ positive $\mathrm{VOSO}_{4}$ electrolyte was prepared by dissolving $0.547 \mathrm{~g} \mathrm{VOSO}_{4} \cdot \mathrm{nH}_{2} \mathrm{O}$ (Dieckmann Chemical Industrial Co. Ltd., Hong Kong, n=2.85 according to thermogravimetric analysis) in $2 \mathrm{~mol} \mathrm{dm}^{-3} \mathrm{H}_{2} \mathrm{SO}_{4}$ solution (total volume is $\left.20 \mathrm{~cm}^{3}\right)$.

All Vanadium redox flow battery (VRF) setup.

An all vanadium redox flow battery was setup as the benchmark for comparison. GF electrodes of $9 \mathrm{~cm}^{2}$ active area were pretreated as above and used as positive and negative electrodes. The positive electrolyte for VRF was a $20 \mathrm{~cm}^{3}$ solution of $0.128 \mathrm{~mol}$ $\mathrm{dm}^{-3} \mathrm{VOSO}_{4}$ and $2 \mathrm{~mol} \mathrm{dm}^{-3} \mathrm{H}_{2} \mathrm{SO}_{4}$, whereas the negative electrolyte was a $20 \mathrm{~cm}^{3}$ solution of $0.5 \mathrm{~mol} \mathrm{dm} \mathrm{V}_{2}\left(\mathrm{SO}_{4}\right)_{3} / \mathrm{VSO}_{4}\left(\sim 1: 1\right.$ volume ratio) and $2 \mathrm{~mol} \mathrm{dm}^{-3} \mathrm{H}_{2} \mathrm{SO}_{4}$. A higher concentration of negative electrolyte was used so that VRF capacity was limited by the positive side. An anion-exchange membrane with active surface area of $13 \mathrm{~cm}^{2}$ (Fumasep FAB, Fumatech) was pre-treated in electrolyte solution overnight, then used as the ionic conductor and barrier for VRF battery ${ }^{39}$. Nitrogen was purged into the negative electrolyte for 10 minutes before pumping into the closed experimental setup. The flow rate of the VRF battery was fixed at $10 \mathrm{~cm}^{3} \mathrm{~min}^{-1}$.

Nickel metal hydride battery $\left(\mathrm{NiMH}_{x}\right)$ setup. 
A $\mathrm{NiMH}_{\mathrm{x}}$ cell was setup as another benchmark for comparison. The $\mathrm{MH}_{\mathrm{x}}$ electrode was prepared as above and coupled with a positive electrode with excess $\mathrm{Ni}(\mathrm{OH})_{2}$ in 2 mol dm ${ }^{-3} \mathrm{KOH}$ aqueous solution. No separator was used in this cell for simplicity.

\section{Electrochemical tests.}

All electrochemical performance tests were carried out at room temperature. Charge and discharge experiments were carried out galvanostatically with a Voltalab PGZ301 potentiostat. For the V-MH system, a $\mathrm{Hg} / \mathrm{Hg}_{2} \mathrm{SO}_{4}$ electrode filled with $2 \mathrm{~mol} \mathrm{dm}{ }^{-3} \mathrm{H}_{2} \mathrm{SO}_{4}$ and a $\mathrm{Hg} / \mathrm{HgO}$ electrode filled with $2 \mathrm{~mol} \mathrm{dm}^{-3} \mathrm{KOH}$ were employed as reference electrodes in acid and alkaline chambers, respectively. The positive electrolyte was circulated by a peristaltic pump (Watson-Marlow Bredel 323) at $10 \mathrm{~cm}^{3} \mathrm{~min}^{-1}$ in the positive chamber through a Phar-Med NSF-51 tubing (Inner diameter is $1.6 \mathrm{~mm}$ ). The hybrid system was left idle for 1 hour initially with the positive electrolyte flowing, and then repeatedly charged and discharged at $9 \mathrm{~mA}$. The corresponding current density is 1 $\mathrm{mA}$ per $\mathrm{cm}^{2}$ of active electrode area. The cut-off voltage is $2.0 \mathrm{~V}$ for charging and $1.6 \mathrm{~V}$ for discharge. The voltages across individual components monitored and recorded by a National Instrument PCI-6221 Data Acquisition Unit were V1: between the positive GF electrode and the $\mathrm{Hg} / \mathrm{Hg}_{2} \mathrm{SO}_{4}$ reference; V2: between the negative $\mathrm{MH}$ electrode and the $\mathrm{Hg} / \mathrm{HgO}$ reference; V3: between the reference electrodes across the membrane; and V4: between the positive and negative electrodes, with polarities of the connections shown in Fig. 1.

The conventional VRF and $\mathrm{NiMH}_{\mathrm{x}}$ batteries were charged and discharged at $9 \mathrm{~mA}$, the same as the V-MH semi-flow system. The cutoff voltages for VRF were $1.46 \mathrm{~V}$ and 0.8 
V. The $\mathrm{NiMH}_{\mathrm{x}}$ battery was charged for 5 hours and then discharged until reaching a cutoff of $0.8 \mathrm{~V}$.

\section{Results and Discussion}

\section{Charge/discharge characteristics.}

Fig. 3 compares the charge and discharge performance of the V-MH semi-flow hybrid battery with the two conventional batteries of acidic VRF and alkaline $\mathrm{NiMH}_{\mathrm{x}}$. At $1 \mathrm{~mA}$

$\mathrm{cm}^{-2}$, a typical charging of the V-MH system takes 4.8 hours reaching the cut-off of $2.0 \mathrm{~V}$ and a discharge of 4.7 hours to $1.6 \mathrm{~V}$. The discharge capacity of the V-MH cell is 42.3 mAh. As shown in Fig. 3, the measured OCV of V-MH after fully charged is $1.93 \mathrm{~V}$. The measured OCV of the V-MH cell was slightly higher than its theoretical value $1.80 \mathrm{~V}$ since the acid and alkaline concentrations were both higher than the standard state concentrations. This OCV value is significantly higher than the theoretical OCVs of the VRF battery and the $\mathrm{NiMH}_{\mathrm{x}}$ battery, which are $1.4 \mathrm{~V}$ and $1.35 \mathrm{~V}$, respectively. These theoretical OCVs are similar to those reported for $\mathrm{VRF}^{11,12}$ and $\mathrm{NiMH}_{\mathrm{x}}$ batteries. ${ }^{30}$ In a typical cycle, V-MH semi-flow hybrid system has higher discharge voltage (1.7 V) than that of individual VRF $(\sim 1.2 \mathrm{~V})$ and $\mathrm{NiMH}_{\mathrm{x}}(\sim 1.28 \mathrm{~V})$ batteries with the same acid or alkaline electrolyte concentration. This coupling of $\mathrm{V}^{4+} / \mathrm{V}^{5+}$ and $\mathrm{MH}_{\mathrm{x}} / \mathrm{MH}$ electrodes increases the overall cell voltage by almost $36 \%$. However, the current density used is much lower than the typical current densities of the order of hundreds of $\mathrm{mA} / \mathrm{cm}^{2}$ in conventional VRF batteries.

Cycle performance. 
The breakdown of voltage losses in the V-MH cell and performance of individual components can be determined by examining the four voltage profiles V1-V4 in Fig. 4. The typical ten charge-discharge cycles are shown which lasted approximately 90 hours. For the overall cell voltage, V4, the charge and discharge plateaus are stable throughout the typical 10 cycles at c.a. $1.93 \mathrm{~V}$, and $1.70 \mathrm{~V}$, respectively. This stability is also reflected in the curves of V1 and V2 with corresponding steady positive and negative electrode reactions. The charge and discharge cycles of V-MH cell demonstrate good reversibility. The voltage difference between charge and discharge is small relative to the average operating voltage.

The present setup of $\mathrm{V}-\mathrm{MH}$ system is positive-limited as the negative $\mathrm{MH}$ capacity is larger with more active material than that of positive $\mathrm{V}^{4+} / \mathrm{V}^{5+}$. This is confirmed by the larger polarization in V1 compared to V2; and the V1 overshoot at the end of charging resembles that of $\mathrm{V} 4$, the overall cell voltage. The voltage loss between charge and discharge of the $\mathrm{MH}$ negative electrode (V2) remains small at $\sim 0.03 \mathrm{~V}$. The voltage across the membrane, $\mathrm{V} 3$ remains stable at 0.4 to $0.6 \mathrm{~V}$, indicating steady and reversible ionic transport across the membrane. V3 is measured between two different types of reference electrodes, without corrected for their difference in standard potentials. The difference between $\mathrm{Hg} / \mathrm{Hg}_{2} \mathrm{SO}_{4}$ (filled with 2 molar $\mathrm{H}_{2} \mathrm{SO}_{4}$ ) and $\mathrm{Hg} / \mathrm{HgO}$ (filled with 2 molar $\mathrm{KOH}$ ) is theoretically estimated to be $0.518 \mathrm{~V}$. With contribution of junction potentials, the V3 was measured to be $0.541 \mathrm{~V}$ during idling without any current passage. After corrected for difference of reference electrodes, the averaged voltage drops across the membrane, was $+0.014 \mathrm{~V}$ and $-0.016 \mathrm{~V}$, during the charge and discharge of first cycle, 
respectively. The areal resistance of the membrane was estimated to be 30 to 40 ohms $\mathrm{cm}^{2}$.

\section{Battery evaluation.}

Efficiencies of the $\mathrm{V}-\mathrm{MH}$ battery are derived from the voltage profiles in Fig. 4 and summarized in Table 2 in terms of coulomb, energy, and voltage efficiencies. In the first cycle, the cell voltage, V4 takes c.a. 4.8 hours to reach 2 V. Then it discharges with a plateau of $1.7 \mathrm{~V}$ for c.a. 4 hours until the cutoff of $1.6 \mathrm{~V}$, yielding $82 \%$ charge or coulomb efficiency. After a 90-hour test with an operating voltage $\sim 1.7 \mathrm{~V}$, the coulomb efficiency reaches $95 \%$ in the $10^{\text {th }}$ cycle. The increase in coulomb efficiency from its initial state can be attributed to reduced crossover of vanadium ions through the membrane. ${ }^{40,41}$ It can also be attributed to improved kinetics in the positive reaction over time when concentration overpotential becomes more evenly distributed with less oxygen evolution. $^{42}$

The calculated average voltage efficiency, defined as (average discharge voltage)/(average charge voltage), is $88 \%$, among the best reported values of conventional VRF batteries, ${ }^{13,15,16}$ as shown in Table 2. Coupled with high coulomb efficiency, the corresponding energy efficiency is $84 \%$, slightly higher than the best reported values of VRF, as shown in Table 2. In additional to high operating voltage and high energy efficiency, the $\mathrm{V}-\mathrm{MH}$ system eliminates the problem arises from air oxidation of $\mathrm{V}^{2+}$. From the present $\mathrm{V}-\mathrm{MH}$ hybrid semi-flow system, the experienced 
energy density ${ }^{1}$, specific energy and power are $1.8 \mathrm{Wh} \mathrm{L}^{-1}$, $46.5 \mathrm{Wh} \mathrm{kg}^{-1}$ and $9.89 \mathrm{~W} \mathrm{~kg}^{-1}$, respectively.

Theoretical cell voltage, cell capacity and specific energy of V-MH.

One factor which currently limits the widespread application of VRF is its low specific energy when compared to other types of batteries. With this semi-flow V-MH battery, the theoretical specific energy can be increased up to $200 \mathrm{Wh} \mathrm{kg}^{-1}$, 3.5 times that of VRF battery, as shown in Table. 1.

The dependence of specific energy on theoretical cell voltage and cell capacity can be graphically illustrated in Fig. 5. Values of theoretical specific energy of VRF, $\mathrm{NiMH}_{\mathrm{x}}$, proposed V-MH and V- $\mathrm{H}_{2}$ hybrid batteries can be compared by the their rectangular areas in Fig. 5. The height of the rectangle is proportional to cell voltage. The width of the rectangle is related to theoretical cell capacity in coulombs/mass of the electrode/electrolyte material. The overall cell capacity is less than a theoretical capacity scaled only to either the positive side or negative side material by Faraday's law. ${ }^{31,43}$ They obey a reciprocal sum relationship, as shown in Fig. 5 with the top arrow indicating the positive side capacity, $C_{+}$and the bottom arrow representing the negative side capacity, $C$. . The theoretical electrode capacity of VRF battery in Fig. 5 is $165 \mathrm{mAh} \mathrm{g}^{-1}$ when scaled to the $\mathrm{V}^{4+} / \mathrm{V}^{5+}$ positive electrolyte; $68.5 \mathrm{mAh} \mathrm{g}^{-1}$, scaled to the $\mathrm{V}^{2+} / \mathrm{V}^{3+}$ negative component; and $48.4 \mathrm{mAh} \mathrm{g}^{-1}$ for the whole cell. ${ }^{31,43}$ Replacing the negative side

\footnotetext{
${ }^{1}$ Energy density is defined as discharge energy divided by the total electrolyte volume $\left(20 \mathrm{~cm}^{3}\right.$ positive electrolyte $+20 \mathrm{~cm}^{3}$ negative electrolyte). The calculation of specific energy and power is based on the weight of active material $\left(1 \mathrm{~g} \mathrm{MH}+0.5471 \mathrm{~g} \mathrm{VOSO}_{4}\right)$ used in the electrochemical battery, excluding the sulfuric acid solution.
} 
with $\mathrm{MH} / \mathrm{MH}_{\mathrm{x}-1}$ or $\mathrm{H}_{2} / \mathrm{OH}^{-}$can improve the cell voltage, and the negative capacity, hence the overall cell capacity, and the specific energy, as geometrically shown in Fig. 5. In principle, this hybrid battery system $(\mathrm{V}-\mathrm{MH})$ of $\mathrm{V}^{4+} / \mathrm{V}^{5+}$ and metal hydride can deliver an overall cell capacity of $111 \mathrm{mAh} \mathrm{g}^{-1}$, cell voltage of $1.8 \mathrm{~V}$, and specific energy of $200 \mathrm{Wh}$ $\mathrm{kg}^{-1}$, much higher than $60.5 \mathrm{Wh} \mathrm{kg}^{-1}$ of conventional VRF battery in Fig. 5.

Using metal hydride as the negative electrode in alkaline, we have successfully demonstrated the viability of the acid/alkaline concept in a high voltage vanadium hybrid semi-flow battery with performance summarized in Table 2 . The next stage would be to apply this $p H$ differential concept to full-flow batteries by replacing the metal-hydride electrode with an alkaline negative electrode/electrolyte that can scale independent of electrode and cell. Specifically, the alkaline hydrogen electrode (-0.83 V vs SHE), a close equivalent of $\mathrm{MH}(-0.8 \mathrm{~V}$ vs SHE), can be demonstrated as a full-flow $p H$ differential battery. This vanadium-hydrogen battery is compared with other batteries in Table 1 . The alkaline hydrogen electrode has a standard potential of $-0.83 \mathrm{~V}$, slightly lower than that of MH and leading to a higher overall cell voltage of $1.83 \mathrm{~V}$. The hydrogen electrode has an extremely high cell capacity and favorable reversible electrochemical kinetics. Both the theoretical specific energy and power of Vanadium- $\mathrm{H}_{2}$ full flow battery are attractively higher than those of V-MH system. This is illustrated in Fig. 5 with the largest rectangle with high voltage $(1.83 \mathrm{~V})$ and high cell capacity $\left(164 \mathrm{mAh} \mathrm{g}^{-1}\right)$. The Vanadium- $\mathrm{H}_{2}$ battery system holds the best prospect of a flow battery with a theoretical specific energy of $300 \mathrm{Wh} \mathrm{kg}^{-1}, 1.5$ times and 5 times that of V-MH and VRF batteries, respectively. In 
terms of costs, both V-MH and V- $\mathrm{H}_{2}$ hybrid systems would be not more expensive than VRF, since metal hydride and/or hydrogen in alkaline are matured systems.

At this stage, the reported high voltage and energy efficiencies of this hybrid semi-flow V-MH battery is demonstrated only at low current density, and far below the level for practical applications. The main bottleneck preventing high current operation is performance of membrane that maintains the $p H$ barrier and transport of preferred ions. Further improvement over the preliminary results of the V-MH system are expected with optimization in electrolyte flow rates, concentrations, distance between electrodes, membrane thickness, or other cell and operation parameters. The power and specific energy of the V-MH hybrid battery may be further increased with scale-up, while the costs reduced, if the marginal increase in pumping energy and loss of ion selectivity at high current can be offset by the higher voltage advantage. Depending on the application, the hybrid system can provide further specific improvement and options over existing options of VRF, lead acid, or $\mathrm{NiMH}_{\mathrm{x}}$ systems. For example, the battery life can be longer than that of lead acid-MH system ${ }^{31,32}$ since no solid-solid phase change occurs in the positive side of V-MH system.

\section{Conclusions}

A novel semi-flow Vanadium-Metal Hydride (V-MH) system (200 Wh kg-1) with 3.5 times higher theoretical specific energy than that of the conventional all vanadium redox flow battery $\left(60.5 \mathrm{Wh} \mathrm{kg}^{-1}\right.$ ) was reported. Hybridizing the $\mathrm{V}^{4+} / \mathrm{V}^{5+}$ couple with metal hydride eliminates the problem of $\mathrm{V}^{2+}$ oxidation as in VRF battery. The average voltage 
of the Vanadium-MH battery system during discharge is around $1.70 \mathrm{~V}$, which is higher than that of individual all vanadium redox flow battery $(1.2-1.4 \mathrm{~V})$ and $\mathrm{NiMH}_{\mathrm{x}}$ battery $(1.25-1.35 \mathrm{~V})$. The Vanadium-MH battery system has good reversibility and efficiency in voltage (88.1\%), coulombic (95\%) and energy (83.7\%), which is critical for its potential application. The best estimate of the present experienced practical energy and power density of this rechargeable semi-flow battery are $46.5 \mathrm{Wh} \mathrm{kg}^{-1}$ and $9.89 \mathrm{~W} \mathrm{~kg}^{-1}$, respectively (based on the lab-scale cell and low current density).

\section{Acknowledgments}

This research is supported by Research Grants Council of Hong Kong (GRF HKU 700209P and GRF HKU 700210P), University of Hong Kong SRT, The University Development Fund on the Initiative of Clean Energy and Environment. We thank Prof. Steven Fung in the Department of Physics, The University of Hong Kong for providing PCI data acquisition equipment. We also thank Constant Environment and Zentric Inc. for their sponsorship and collaboration.

\section{References}

1. $\quad$ L. H. Thaller, NASA TMX-71540 (1974).

2. L. H. Thaller, U.S. Patent 3,996,064 (1974).

3. R. F. Savinell, C. C. Liu, R. T. Galasco, S. H. Chiang and J. F. Coetzee, J. Electrochem. Soc., 126, 357 (1979).

4. M. Bartolozzi, J. Power Sources, 27, 219 (1989).

5. Q. Lai, H. Zhang, X. Li, L. Zhang and Y. Cheng, J. Power Sources, 235, 1 (2013). 
6. K. T. Cho, P. Ridgway, A. Z. Weber, S. Haussener, V. Battaglia and V. Srinivasan, J. Electrochem. Soc., 159, A1806 (2012).

7. P. K. Leung, C. Ponce-de-León and F. C. Walsh, Electrochim. Acta, 80, 7 (2012).

8. F. Xiong, D. Zhou, Z. Xie and Y. Chen, Appl. Energy, 99, 291 (2012).

9. H. Kreutzer, V. Yarlagadda and T. V. Nguyen, J. Electrochem. Soc., 159, F331 (2012).

10. L. Joerissen, J. Garche, C. Fabjan and G. Tomazic, J. Power Sources, 127, 98 (2004).

11. M. Skyllas-Kazacos and F. Grossmith, J. Electrochem. Soc., 134, 2950 (1987).

12. M. Skyllas-Kazacos, M. Rychick and R. G. Robins, US Patent 4,786,567 (1988).

13. C. Ponce-de-León, A. Frías-Ferrer, J. González-García, D. A. Szánto and F. C. Walsh, J. Power Sources, 160, 716 (2006).

14. Y. Lu and J. B. Goodenough, J. Mater. Chem., 21, 10113 (2011).

15. T. Mohammadi and M. Skyllas-Kazacos, J. Mem. Sci., 98, 77 (1995).

16. Q. H. Liu, G. M. Grim, A. B. Papandrew, A. Turhan, T. A. Zawodzinski and M. M. Mencha, J. Electrochem. Soc., 159, A1246 (2012).

17. V. Livshits, A. Ulus and E. Peled, Electrochem. Commun., 8, 1358 (2006).

18. J. P. N. Ross, U.S. Patent 4,842,963 (1989).

19. J. D. Dunlop, G. M. Rao and T. Y. Yi, NASA handbook for nickel-hydrogen batteries, NASA Reference Publication 1314 (1993).

20. L. H. Thaller and A. H. Zimmerman, NASA/TP-2003-211905 (2003).

21. C. Menictas and M. Skyllas-Kazacos, J. Appl. Electrochem., 41, 1223 (2011). 
22. L. Y. Li, S. W. Kim, W. Wang, M. Vijayakumar, Z. M. Nie, B. W. Chen, J. L. Zhang, G. G. Xia, J. Z. Hu, G. Graff, J. Liu and Z. G. Yang, Adv. Energy Mater., 1, 394 (2011).

23. S. Liu, G. L. Pan, N. F. Yan and X. P. Gao, Energy Environ. Sci., 3, 1732 (2010).

24. J. P. Zheng, P. Andrei, M. Hendrickson and E. J. Plichta, J. Electrochem. Soc., 158, A43 (2011).

25. H. S. Zhou, Y. G. Wang, H. Q. Li and P. He, ChemSusChem, 3, 1009 (2010).

26. M. Skyllas-Kazacos, J. Power Sources, 124, 299 (2003).

27. A. Hazza, D. Pletcher and R. Wills, J. Power Sources, 149, 103 (2005).

28. J. L. Cohen, D. J. Volpe, D. A. Westly, A. Pechenik and H. D. Abruña, Langmuir, 21, 3544 (2005).

29. S. A. Cheng and K. Y. Chan, US Patent 7,344,801 (2008).

30. S. A. Cheng and K. Y. Chan, ECS Trans., 25, 213 (2010).

31. H. Q. Li, G. M. Weng, C. Y. V. Li and K. Y. Chan, Electrochim. Acta, 56, 9420 (2011).

32. G. M. Weng, C. Y. V. Li and K. Y. Chan, ECS Trans., 41, 133 (2012).

33. G. M. Weng, C. Y. V. Li and K. Y. Chan, Meet. Abstra. Electrochem. Soc., MA2012-02, 372 (2012).

34. G. M. Weng, C. Y. V. Li and K. Y. Chan, ECS Trans., 53, 39(2013).

35. H. Strathmann, Ion-exchange membrane separation processes, p. 184-185, Elsevier, Amsterdam (2004).

36. A. J. B. Kemperman, Handbook on bipolar membrane technology, p. 12-16, Twente University Press, Enschede, The Netherlands (2000). 
37. R. Ferrigno, A. D. Stroock, T. D. Clark, M. Mayer and G. M. Whitesides, J. Am. Chem. Soc., 124, 12930 (2002).

38. M. Ünlü, J. Zhou and P. A. Kohl, J. Phys. Chem. C, 113, 11416 (2009).

39. S. Zhang, C. Yin, D. Xing, D. Yang and X. Jian, J. Mem. Sci., 363, 243 (2010).

40. Q. Luo, H. Zhang, J. Chen, P. Qian and Y. Zhai, J. Mem. Sci., 311, 98 (2008).

41. J. Xi, Z. Wu, X. Teng, Y. Zhao, L. Chen and X. Qiu, J. Mater. Chem., 18, 1232 (2008).

42. A. A. Shah, M. J. Watt-Smith and F. C. Walsh, Electrochim. Acta, 53, 8087 (2008).

43. H. Q. Li, Y. G. Wang, H. T. Na, H. M. Liu and H. S. Zhou, J. Am. Chem. Soc., 131, 15098 (2009).

\section{Figure Captions}

Figure 1. Schematic drawing of the V-MH hybrid system with positive electrolyte flow. $\mathrm{V} 1=\phi_{\mathrm{positive}}-\phi_{\mathrm{Hg}_{\mathrm{Hg}} \mathrm{SO}_{4}}$ is the potential difference between graphite felt (GF) electrode (positive electrode) and reference electrode $\left(\mathrm{Hg} / \mathrm{Hg}_{2} \mathrm{SO}_{4}\right) . \mathrm{V} 2=\phi_{\text {negative }}-\phi_{\mathrm{Hg} / \mathrm{HgO}}$ is the potential difference between $\mathrm{MH}_{\mathrm{x}} / \mathrm{MH}_{\mathrm{x}-1}$ electrode (negative electrode) and reference electrode $(\mathrm{Hg} / \mathrm{HgO}) . \quad \mathrm{V} 3=\phi_{\mathrm{Hg}_{\mathrm{Hg}} \mathrm{SO}_{4}}-\phi_{\mathrm{Hg} / \mathrm{HgO}}$ is the potential or potential difference between reference electrodes $\mathrm{Hg} / \mathrm{Hg}_{2} \mathrm{SO}_{4}$ and $\mathrm{Hg} / \mathrm{HgO}$ across the bipolar membrane. $\mathrm{V} 4=\phi_{\text {positive }}-\phi_{\text {negative }}$ is the potential difference between GF electrode and $\mathrm{MH}_{\mathrm{x}} / \mathrm{MH}_{\mathrm{x}-1}$ electrode or overall cell voltage. 
Figure 2. Cyclic voltammetry at $20 \mathrm{mV} \mathrm{s}^{-1}$ for different graphite felt electrodes in solution of $0.026 \mathrm{~mol} \mathrm{dm}^{-3} \mathrm{VOSO}_{4}$ and $2 \mathrm{~mol} \mathrm{dm}^{-3} \mathrm{H}_{2} \mathrm{SO}_{4}$. The working electrode is graphite felt with or without pretreatment. The counter electrode is a graphite plate and the reference electrode is $\mathrm{Ag} / \mathrm{AgCl}$ in $3 \mathrm{~mol} \mathrm{dm}^{-3} \mathrm{NaCl}$.

Figure 3. Typical charge/discharge curves at $1 \mathrm{~mA} \mathrm{~cm}^{-2}$ for $\mathrm{NiMH}_{\mathrm{x}}, \mathrm{VRF}$, and hybrid semi-flow V-MH batteries.

Figure 4. Ten charge/discharge cycles of the V-MH battery. V1 is the potential difference between the positive graphite felt (GF) electrode and the $\mathrm{Hg} / \mathrm{Hg}_{2} \mathrm{SO}_{4}$ reference: $\mathrm{V} 1=\phi_{\text {positive }}-\phi_{\mathrm{Hg}_{\mathrm{Hg}} \mathrm{HO}_{4}}$; V2 is the potential difference between the negative $\mathrm{MH}_{\mathrm{x}} / \mathrm{MH}_{\mathrm{x}-1}$ electrode and the $\mathrm{Hg} / \mathrm{HgO}$ reference electrode: $\mathrm{V} 2=\phi_{\text {negative }}-\phi_{\mathrm{Hg} / \mathrm{HgO}}$; V3 is the voltage across the bipolar membrane measured by the $\mathrm{Hg} / \mathrm{Hg}_{2} \mathrm{SO}_{4}$ reference electrode and the $\mathrm{Hg} / \mathrm{HgO}$ reference electrode: $\mathrm{V} 3=\phi_{\mathrm{Hg}_{\mathrm{Hg}} \mathrm{SO}_{4}}-\phi_{\mathrm{Hg} / \mathrm{HgO}} ; \mathrm{V} 4$ is the cell voltage which is the potential difference between the GF electrode and $\mathrm{MH}_{\mathrm{X}} / \mathrm{MH}_{\mathrm{x}-1}$ electrode: $\mathrm{V} 4=\phi_{\text {positive }}-\phi_{\text {negative }} \cdot$

Figure 5. Theoretical cell voltage, cell capacity, and specific energy of selected pairing of positive and negative electrodes/electrolytes. (The theoretical cell capacity is calculated by $C=C_{+} /\left(1+C_{+} / C_{-}\right)$, where $C_{+}$and $C_{\text {- }}$ represent the theoretical capacity of positive electrode/electrolyte material (width of bar at the top) and negative electrode 
material (width of bar at the bottom), respectively ${ }^{31,43} \cdot C_{+}$and $C_{\text {- }}$ are scaled by Faraday’s law to their individual active material. In VRF battery, $\mathrm{VOSO}_{4}$ and $\mathrm{V}_{2}\left(\mathrm{SO}_{4}\right)_{3}$ are the active material for $\mathrm{V}^{4+} / \mathrm{V}^{5+}$ and $\mathrm{V}^{2+} / \mathrm{V}^{3+}$ redox couples, respectively. The specific energy is calculated as $C \times$ Cell voltage.) 


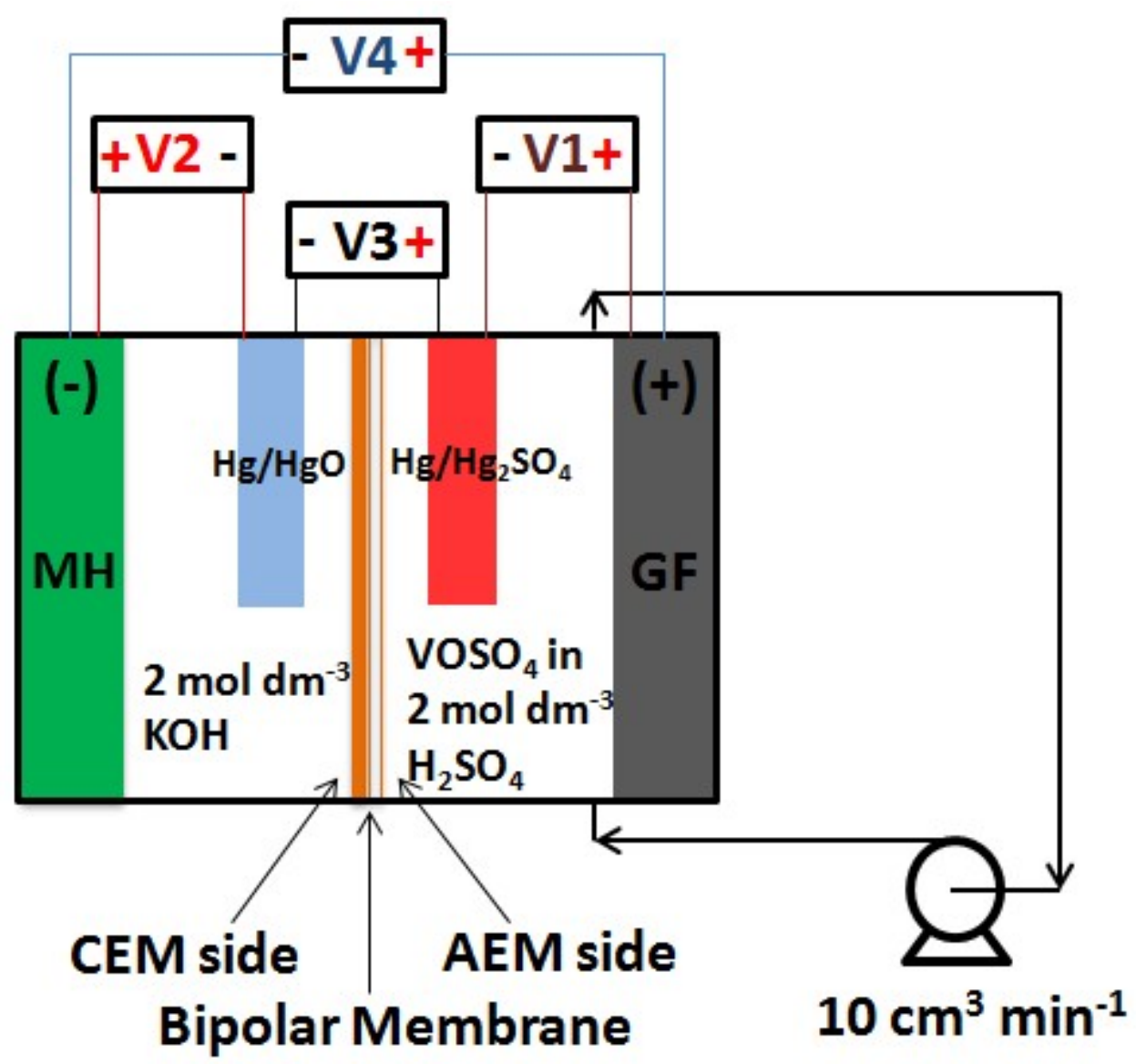

Figure 1. Schematic drawing of the V-MH hybrid system with positive electrolyte flow. $\mathrm{V} 1=\phi_{\text {positive }}-\phi_{\mathrm{Hg}_{\mathrm{Hg}} \mathrm{SO}_{4}}$ is the potential difference between graphite felt (GF) electrode (positive electrode) and reference electrode $\left(\mathrm{Hg} / \mathrm{Hg}_{2} \mathrm{SO}_{4}\right) . \mathrm{V} 2=\phi_{\text {negative }}-\phi_{\mathrm{Hg} / \mathrm{HgO}}$ is the potential difference between $\mathrm{MH}_{\mathrm{x}} / \mathrm{MH}_{\mathrm{x}-1}$ electrode (negative electrode) and reference electrode $(\mathrm{Hg} / \mathrm{HgO}) . \mathrm{V} 3=\phi_{\mathrm{Hg}_{\mathrm{Hg}} \mathrm{SO}_{4}}-\phi_{\mathrm{Hg} / \mathrm{HgO}}$ is the potential or potential difference between reference electrodes $\mathrm{Hg} / \mathrm{Hg}_{2} \mathrm{SO}_{4}$ and $\mathrm{Hg} / \mathrm{HgO}$ across the bipolar membrane. $\mathrm{V} 4=\phi_{\text {positive }}-\phi_{\text {negative }}$ is the potential difference between GF electrode and $\mathrm{MH}_{\mathrm{X}} / \mathrm{MH}_{\mathrm{x}-1}$ electrode or overall cell voltage. 


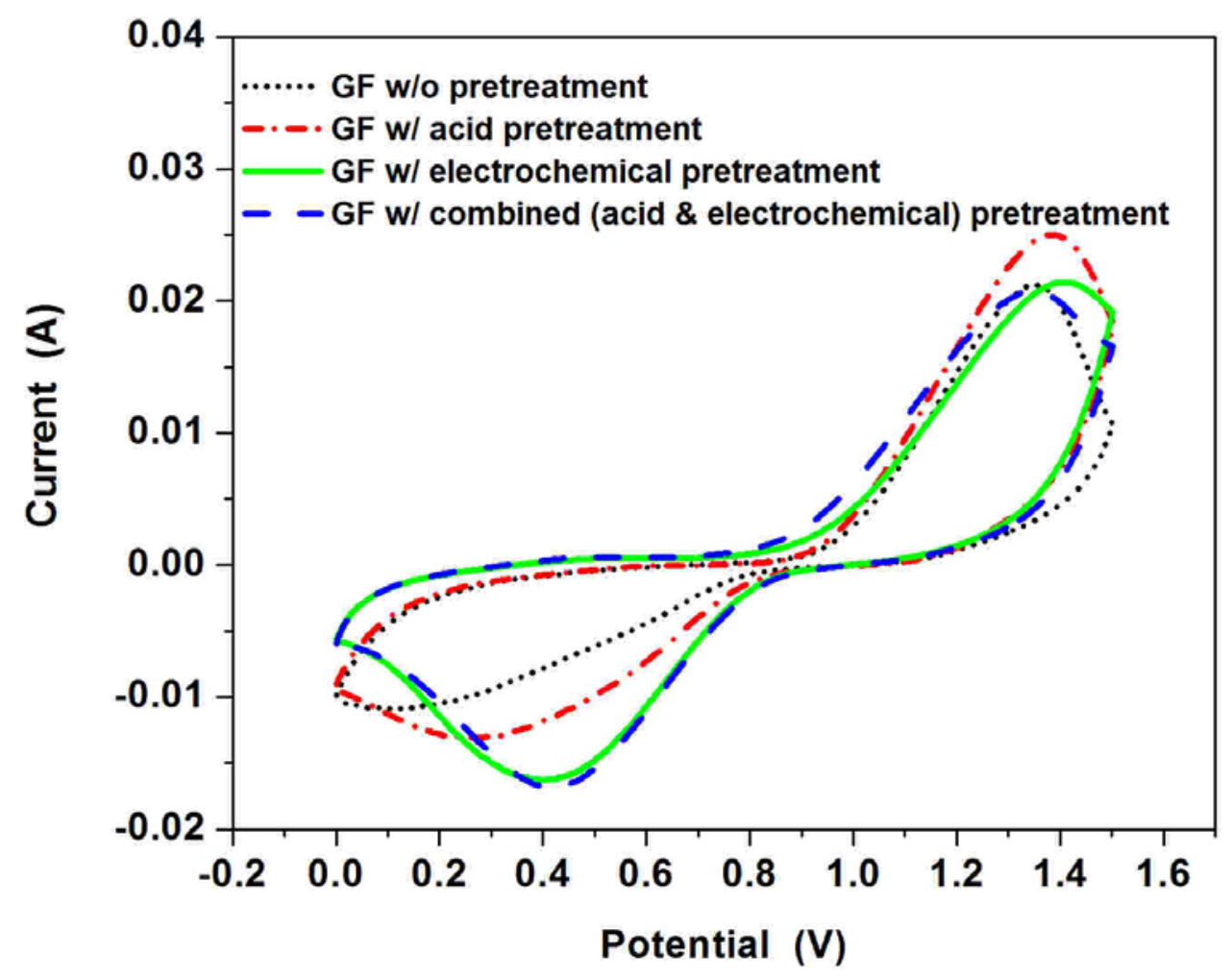

Figure 2. Cyclic voltammetry at $20 \mathrm{mV} \mathrm{s}^{-1}$ for different graphite felt electrodes in solution of $0.026 \mathrm{~mol} \mathrm{dm}^{-3} \mathrm{VOSO}_{4}$ and $2 \mathrm{~mol} \mathrm{dm}^{-3} \mathrm{H}_{2} \mathrm{SO}_{4}$. The working electrode is graphite felt with or without pretreatment. The counter electrode is a graphite plate and the reference electrode is $\mathrm{Ag} / \mathrm{AgCl}$ in $3 \mathrm{~mol} \mathrm{dm}^{-3} \mathrm{NaCl}$. 


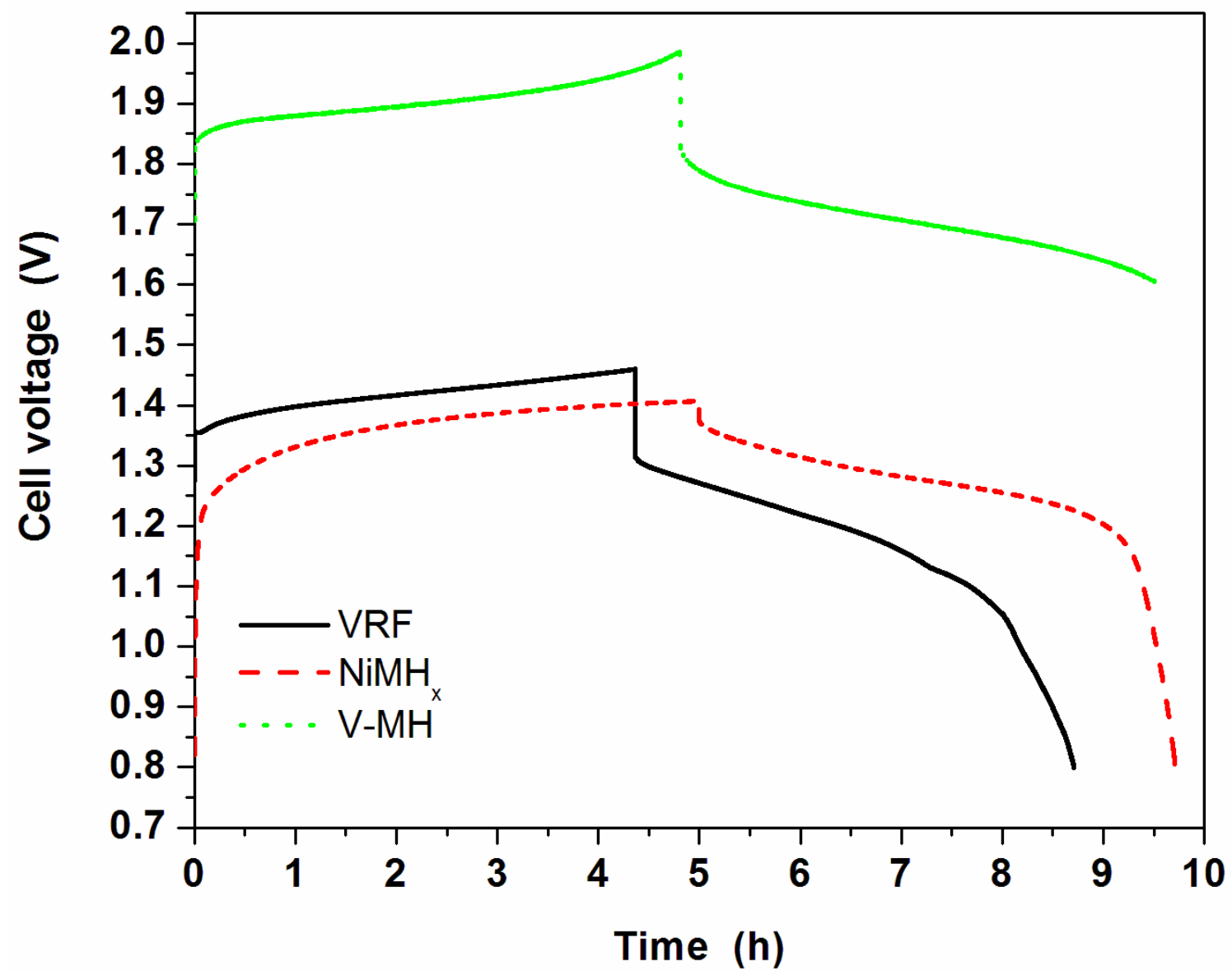

Figure 3. Typical charge/discharge curves at $1 \mathrm{~mA} \mathrm{~cm}^{-2}$ for $\mathrm{NiMH}_{\mathrm{x}}, \mathrm{VRF}$, and hybrid semi-flow V-MH batteries. 


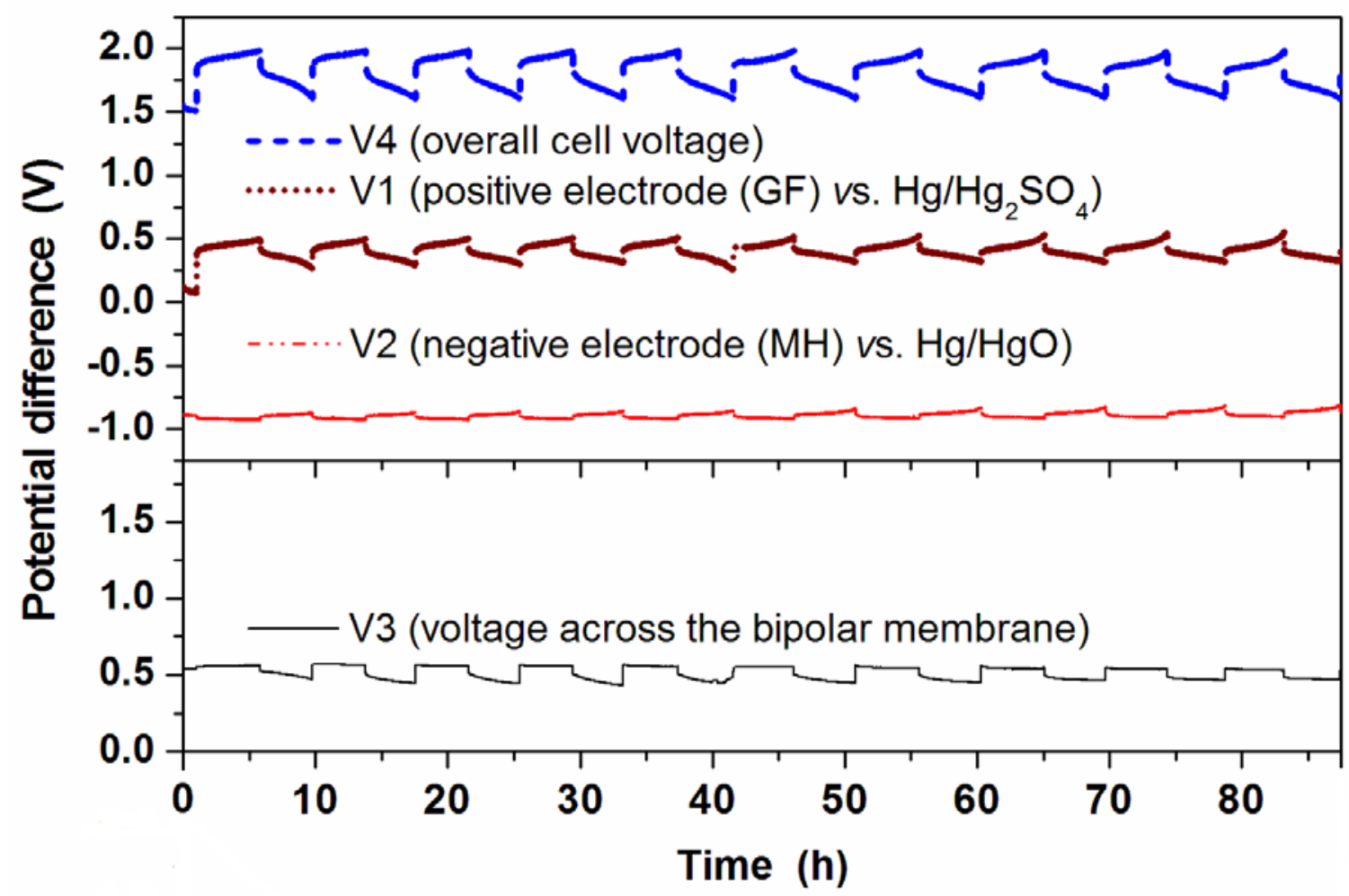

Figure 4. Ten charge/discharge cycles of the V-MH battery. V1 is the potential difference between the positive graphite felt (GF) electrode and the $\mathrm{Hg} / \mathrm{Hg}_{2} \mathrm{SO}_{4}$ reference: $\mathrm{V} 1=\phi_{\text {positive }}-\phi_{\mathrm{Hg}_{\mathrm{Hg}} \mathrm{SO}_{4}}$; $\mathrm{V} 2$ is the potential difference between the negative $\mathrm{MH}_{\mathrm{x}} / \mathrm{MH}_{\mathrm{x}-1}$ electrode and the $\mathrm{Hg} / \mathrm{HgO}$ reference electrode: $\mathrm{V} 2=\phi_{\text {negative }}-\phi_{\mathrm{Hg} / \mathrm{HgO}}$; $\mathrm{V} 3$ is the voltage across the bipolar membrane measured by the $\mathrm{Hg} / \mathrm{Hg}_{2} \mathrm{SO}_{4}$ reference electrode and the $\mathrm{Hg} / \mathrm{HgO}$ reference electrode: $\mathrm{V} 3=\phi_{\mathrm{Hg} / \mathrm{Hg}_{2} \mathrm{SO}_{4}}-\phi_{\mathrm{Hg} / \mathrm{HgO}}$; $\mathrm{V} 4$ is the cell voltage which is the potential difference between the GF electrode and $\mathrm{MH}_{\mathrm{x}} / \mathrm{MH}_{\mathrm{x}-1}$ electrode: $\mathrm{V} 4=\phi_{\text {positive }}-\phi_{\text {negative }}$. 


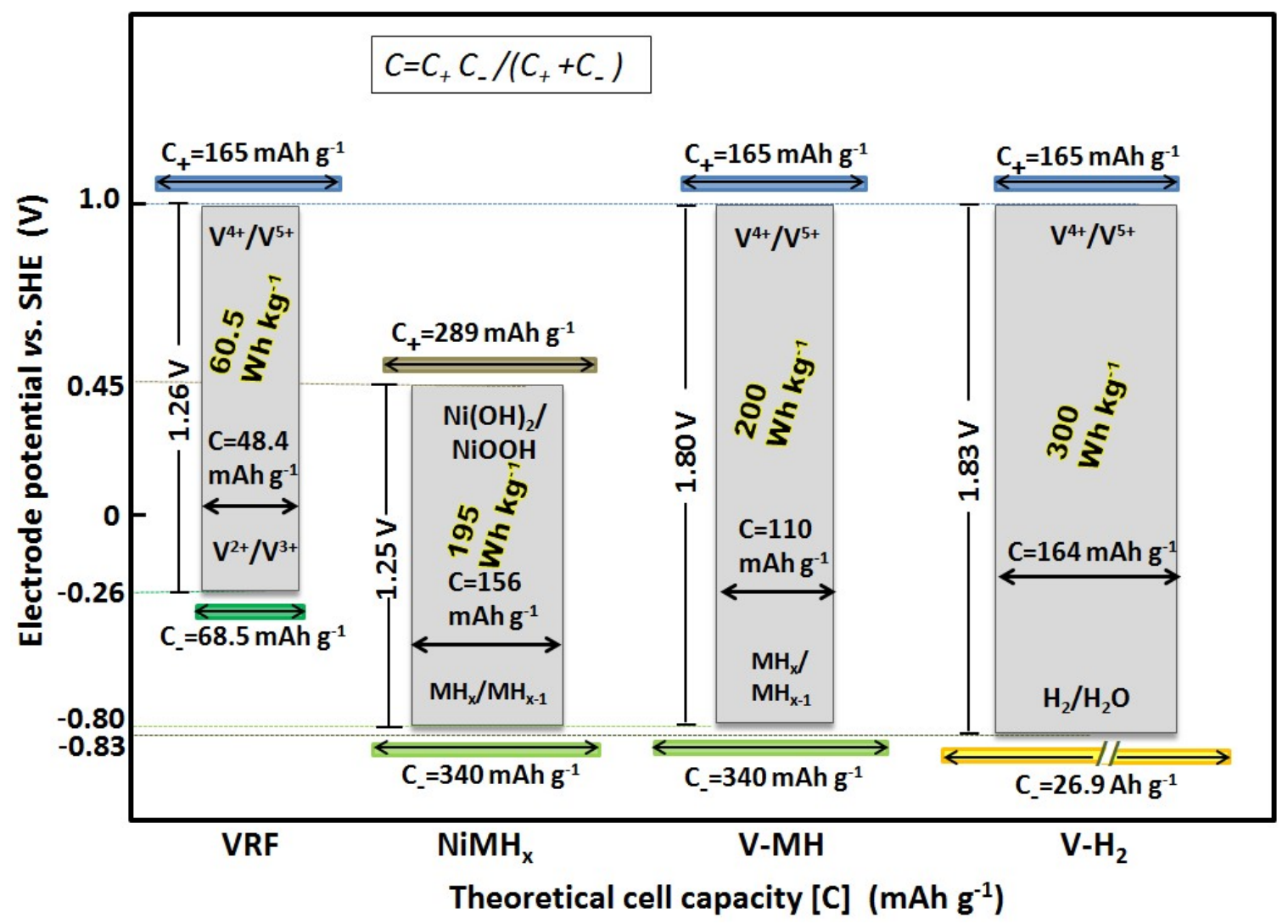

Figure 5. Theoretical cell voltage, cell capacity, and specific energy of selected pairing of positive and negative electrodes/electrolytes. (The theoretical cell capacity is calculated by $C=C_{+} /\left(1+C_{+} / C_{-}\right)$, where $C_{+}$and $C_{\text {- }}$ represent the theoretical capacity of positive electrode/electrolyte material (width of bar at the top) and negative electrode material (width of bar at the bottom), respectively ${ }^{31,43} . C_{+}$and $C_{\text {- }}$ are scaled by Faraday's law to their individual active material. In VRF battery, $\mathrm{VOSO}_{4}$ and $\mathrm{V}_{2}\left(\mathrm{SO}_{4}\right)_{3}$ are the active material for $\mathrm{V}^{4+} / \mathrm{V}^{5+}$ and $\mathrm{V}^{2+} / \mathrm{V}^{3+}$ redox couples, respectively. The specific energy is calculated as $C \times$ Cell voltage.) 


\section{List of Tables}

Table 1. Characteristics of some rechargeable storage batteries. ( ${ }^{a}$ Operating voltage)

Table 2. Comparison of V-MH and VRF batteries in terms of voltage, coulombic, and energy efficiencies. 
Table 1. Characteristics of some rechargeable storage batteries. ( ${ }^{\mathrm{a}}$ Operating voltage)

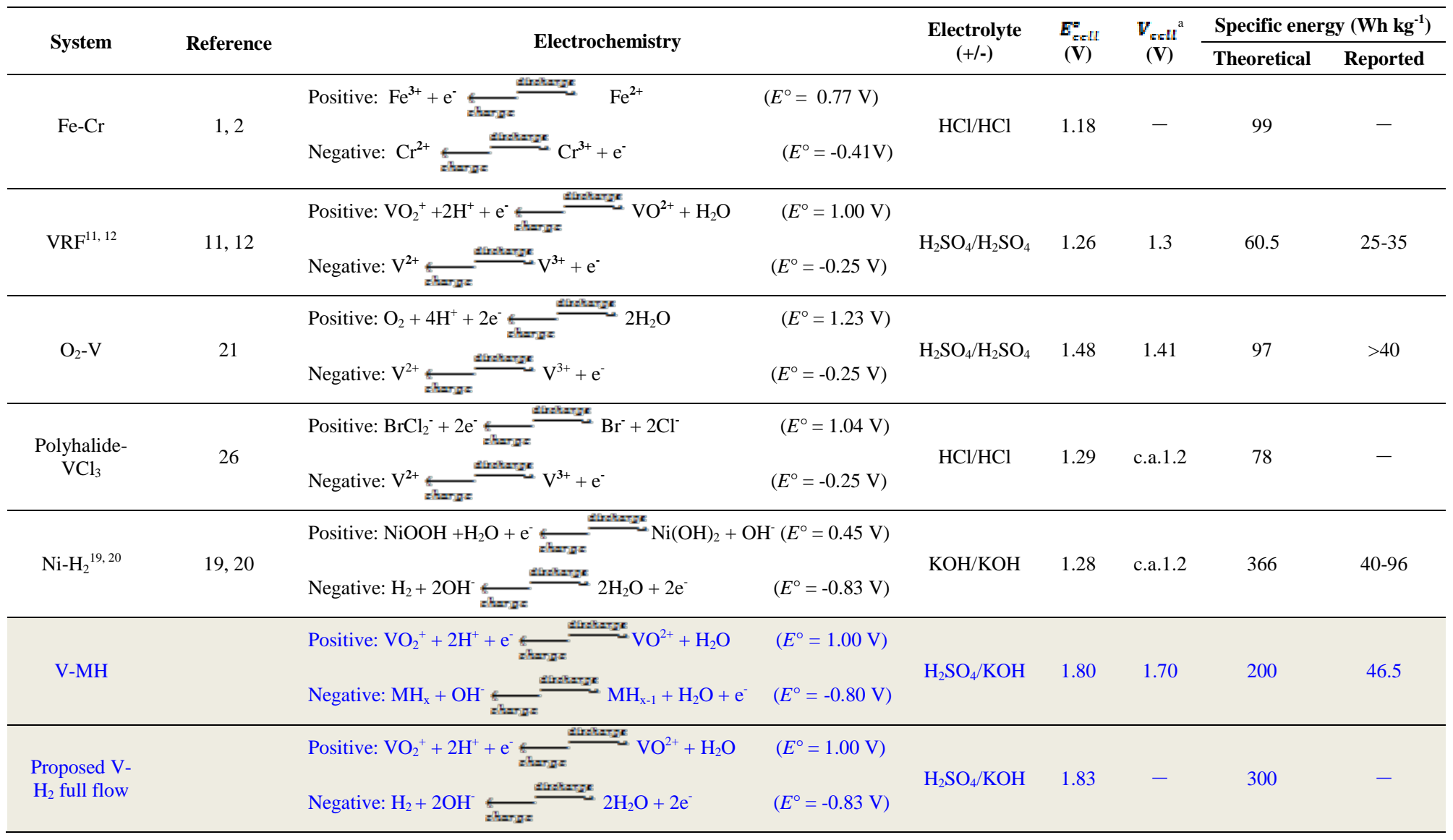


Table 2. Comparison of V-MH and VRF batteries in terms of voltage, coulombic, and energy efficiencies.

\begin{tabular}{|c|c|c|c|}
\hline & $\begin{array}{c}\text { VRF } \\
\text { (this work) }\end{array}$ & $\begin{array}{c}\text { VRF } \\
\text { [ref. 13, 15, 16] }\end{array}$ & V-MH \\
\hline $\begin{array}{l}\text { Typical discharge } \\
\text { voltage, } \mathrm{V}\end{array}$ & 1.23 & $1.26-1.4$ & 1.70 with a cutoff at $1.6 \mathrm{~V}$ \\
\hline $\begin{array}{c}\text { Average voltage } \\
\text { Efficiency(eq. 1), \% }\end{array}$ & $85.3^{\S}$ & $\begin{array}{c}\text { 62-73 } \\
\text { 85 } 5^{\text {[ref.13] } 15]} \\
91.2^{\text {[ref. 16] }}\end{array}$ & $88.1^{\dagger}$ \\
\hline $\begin{array}{l}\text { Average coulombic } \\
\text { efficiency(eq. } 2 \text { ), \% }\end{array}$ & $81.6^{\S}$ & 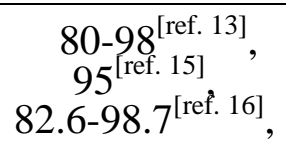 & $95^{\dagger}$ \\
\hline $\begin{array}{c}\text { Average energy } \\
\text { Efficiency(eq. 3), \% }\end{array}$ & $69.6^{\S}$ & $\begin{array}{c}\text { 66-75 [ref. 13] } \\
77-83^{\text {[ref. 15]' }} \\
75.3^{\text {[ref. 16] }},\end{array}$ & $83.7^{\dagger}$ \\
\hline
\end{tabular}

Voltage efficiency: $\eta_{V}=V_{\text {discharge }} / V_{\text {charge }}$

Coulomb/charge efficiency: $\eta_{c}=Q_{\text {discharge }} / Q_{\text {charge }}=\left(I t_{\text {discharge }}\right) /\left(I t_{\text {charge }}\right)$

Energy efficiency: $\eta_{P}=E_{\text {discharge }} / E_{\text {charge }}=\left(V_{\text {discharge }} I t_{\text {discharge }}\right) /\left(V_{\text {charge }} I t_{\text {charge }}\right)$

(eq. 1)

(eq. 2)

(eq. 3)

${ }^{\S}$ Average over 2 cycles

${ }^{\dagger}$ Average over 10 cycles 